\title{
Hormonal Changes in Clomiphene Citrate Cycles in Unexplained Infertility Can Predict Follicle Development?
}

\author{
Evrim Ebru Kovalak ${ }^{1}$, Sefik Eser Ozyurek ${ }^{2}$, Ozlem Karabay Akgul ${ }^{1}$ and Tolga Karacan ${ }^{1}$ \\ ${ }^{1}$ Department of Obstetrics and Gynecology, University of Health Sciences, Bagcilar Training and Research Hospital, Istanbul, Turkey \\ ${ }^{2}$ Department of Gynecologic Oncology, University of Health Sciences, Zeynep Kamil Women's and Children's Disease Training and \\ Research Hospital, Istanbul, Turkey
}

\begin{abstract}
Objectives: To examine the intra-cycle and inter-cycle hormonal changes in the clomiphene citrate (CC) cycle in women with unexplained infertility; and to determine the factors that may predict follicle development or CC failure.

Study Design: Descriptive study.

Place and Duration of Study: This study was conducted at the Bagcilar Training and Research Hospital, Istanbul, Turkey from August 2019 to March 2020.

Methodology: Fifty-two women with unexplained infertility were included. Fifty-two cycles given 50 mg of CC but without follicle development were accepted as Group I. In the next cycle, 48 cycles given 100 mg of CC were accepted as Group II. During every cycle, serum hormone ( $F S H, L H, E_{2}, P_{4}, A_{4}$, DHEA-S, T, 17-OHP) levels were measured on days 2, 3, 4 or 5 of the cycle (basal day), and on the days when the leading follicle was triggered (trigger day). Endogenous hormone changes were compared in both the groups with and without follicle development as well as in those who could conceive and those who could not conceive.

Results: Basal day FSH and DHEA-S values were found to be statistically significantly higher in women with follicle development than those without follicle development ( $p=0.02$ and $p=0.039$, respectively). The trigger day FSH value was found to be significantly lower in women who conceived compared to the basal day value $(p=0.004)$. The relatively high $P_{4}$ value ( $p=0.008$ ) on the basal day (contingent upon it was not exceeding the $0.5 \mathrm{ng} / \mathrm{mL}$ threshold) and the low FSH value ( $p=0.015$ ) on the trigger day were found to be statistically significantly different in women who had conceived compared to those who had not.

Conclusion: Basal serum FSH, $\mathrm{P}_{4}$ and DHEA-S levels can be used as predictors of ovulation in CC cycles in women with unexplained infertility by determining a threshold value with more comprehensive studies to be conducted in the future.
\end{abstract}

Key Words: Androgens, Ovarian stimulation, Clomiphene citrate, Unexplained infertility, Induction of ovulation, Prediction.

How to cite this article: Kovalak EE, Ozyurek SE, Akgul OK, Karacan T. Hormonal Changes in Clomiphene Citrate Cycles in Unexplained Infertility Can Predict Follicle Development?. J Coll Physicians Surg Pak 2022; 32(01):25-32.

\section{INTRODUCTION}

The cause of unexplained infertility cannot be determined in $30 \%$ of all infertile couples. The first approach in the treatment of unexplained infertility is the stimulation of oocyte production. For this reason, clomiphene citrate has been used as a first line treatment for unexplained infertility for over four decades. ${ }^{1}$

Correspondence to: Dr. Evrim Ebru Kovalak, Department of Obstetrics and Gynecology, University of Health Sciences, Bagcilar Training and Research Hospital, Istanbul, Turkey

E-mail: evrimebru@yahoo.com

Received: June 26, 2021; Revised: September 16, 2021;

Accepted: November 23, 2021

DOI: https://doi.org/10.29271/jcpsp.2022.01.25
While the efficacy of clomiphene citrate (CC) in the treatment of oligoanovulation- or anovulation-related infertility has been clearly demonstrated, ${ }^{2,3}$ its efficacy in ovulatory women with unexplained infertility is less clear. ${ }^{4}$ Despite this, CC is the most commonly prescribed to ovulatory women with unexplained infertility. CC is a competitive inhibitor of oestrogen that binds to oestrogen receptors, resulting in an increase of circulating concentrations of FSH and LH. CC is taken orally with a starting dose of one tablet $(50 \mathrm{mg}$ ) daily for five days. Ovulation generally occurs five to twelve days after the last tablet. If a poor response is observed, the dose of $\mathrm{CC}$ can then be increased to a maximum dose of $150 \mathrm{mg}$ per day. ${ }^{5}$

No laboratory or clinical parameters have hitherto been established that have been able to estimate the $\mathrm{CC}$ dose required to follicle development. It is also unclear as to why CC does not initiate ovulation in some cycles and, due to hormonal changes, it initiates ovulation with dose increases in the following cycle. Moreover, this drug is associated with multiple pregnancy and 
increased risks of ovarian malignancy with the use exceeding six months. Understanding the effectiveness of clomiphene in ovulatory women with unexplained infertility is, therefore, extremely important.

The aim of this study was to examine the relationship between follicle development and pregnancy by examining the intra-cycle and inter-cycle hormonal changes induced by $\mathrm{CC}$ in women with unexplained infertility; and to determine the factors that may predict follicle development or CC failure.

\section{METHODOLOGY}

This descriptive study was conducted in a tertiary referral hospital infertility outpatient clinic from August 2019 to March 2020.

Fifty-two women with unexplained infertility were included in the study. Fifty-two cycles given $50 \mathrm{mg}$ of CC but without follicle development were accepted as Group I. For these patients, $100 \mathrm{mg}$ of CC was planned in their second cycle. Four patients were out of follow-up. The remaining 48 women were given $100 \mathrm{mg}$ of CC for the second cycle. The second cycles were accepted as Group II.

Women aged 20-35, without uterine anomaly and bilateral tubal obstruction and who were hormonally eugonadotropic, were included in the study. Serum anti-mullerian hormone (AMH) levels, body mass index (BMI), and type of infertility (primary/secondary) were recorded. Male partners with normal spermiograms or mild male factor infertility, were included in the study. Sperm counts less than 20 million/mL or normal morphology less than $4 \%$, or sperm motility below $40 \%$ with more than one of the parameters, or male partners with a total motile sperm count of less than 5 million/mL after washing, were not included in the study.

The following exclusion criteria were applied: the use of co-medication (metformin, myo-inositol, cortisone/prednisolone), severe male factor, additional endocrine or medical disorders, recurrent pregnancy loss, endometriosis, ovarian cysts, previous pelvic surgery and women with $\mathrm{AMH}$ less than $1.1 \mathrm{ng} / \mathrm{mL}$.

In the power analysis performed with the G*Power 3.1 programme related to this study, the FSH effect size of the study groups was found to be 0.87 (alpha error probability $=0.05) .{ }^{6}$ In the sample size analysis performed with the power value of 0.80 , the total number of samples required to be taken was found to be 48 patients for each group.

Pre-stimulation hormonal testing [FSH, LH, estradiol $\left(E_{2}\right)$, progesterone $\left(P_{4}\right)$, androstenedione $\left(A_{4}\right)$, dehydroepiandrosterone sulfate (DHEA-S), total testosterone (T) and 17 hydroxyprogesterone (17-OHP), AMH, thyroid stimulating hormone (TSH), prolactin $(\mathrm{PRL})]$ and folliculometry with transvaginal sonography were performed on the second to fifth day of the menstrual cycle (basal day). If blood $\mathrm{E}_{2}$ levels were $<50 \mathrm{pg} / \mathrm{mL}$ and blood $\mathrm{P}_{4}$ levels were $<0.5 \mathrm{ng} / \mathrm{mL}$ on the basal day, CC
(Klomen 50 mg; Kocak Farma) would be started with an initial dose of $50 \mathrm{mg} /$ day from the fifth to the ninth day of the menstrual cycle. Beginning with the eleventh day, patients would undergo transvaginal sonographic monitoring of follicular growth and endometrial thickening every other day. If an ovarian response did not develop in the 21-day follow-up, the cycle was cancelled. Therefore, hormonal evaluation was not performed on the trigger day in Group I because there was no trigger day. $20 \mathrm{mg}$ of dydrogesterone was administered orally for ten days to induce menstrual bleeding.

For women unable to achieve ovulation with CC $50 \mathrm{mg}$, a CC $100 \mathrm{mg}$ treatment would be started in the next cycle. The cycle was followed up in the same way. When the leading follicle reached diameter of $18-20 \mathrm{~mm}$, ovulation was induced by subcutaneous administration of choriogonadotropin alpha (Ovitrelle 250 gr Merck Serono-Turkey) (rHCG) (trigger day). Before rHCG application, hormonal testing (FSH, LH, $E_{2}, P_{4}, A_{4}$, DHEA-S, T, 17-OHP) was performed again. Timing intercourse or intrauterine insemination were performed at 36-40 hours. At 20 days after insemination, conception was confirmed if the blood beta-HCG level was higher than $20 \mathrm{mIU} / \mathrm{mL}$. The cycle was cancelled, if there were two or more follicles larger than $16 \mathrm{~mm}$ on the trigger day, or if the blood $E_{2}$ level was $>1500 \mathrm{pg} / \mathrm{mL}$.

All hormones were measured using the UniCel DxI 800 immunochemistry analyser (Beckman Coulter Inc., USA), according to the manufacturer's assay instructions and requirements in the biochemistry laboratory of this hospital. The following reference intervals were accepted: 3.85-12.5 mIU/mL for $\mathrm{FSH}, 2.4-12.6 \mathrm{ml}$ $\mathrm{U} / \mathrm{mL}$ for $\mathrm{LH}, 22.4-115 \mathrm{pg} / \mathrm{mL}$ for $E_{2}, 0.31-1.52 \mathrm{ng} / \mathrm{mL}$ for $P_{4}$, 0.26-2.14 ng/mL for $\mathrm{A}_{4}, 18-391 \mathrm{mg} / \mathrm{dL}$ for DHEA-S, 0.1-0.75 ng $/ \mathrm{mL}$ for $\mathrm{T}, 0.2-1.3 \mathrm{ng} / \mathrm{mL}$ for $17-\mathrm{OHP}, 0-9.16 \mathrm{ng} / \mathrm{mL}$ for $\mathrm{AMH}$, 0.38-5.33 ng/mL for TSH and 3.34-26.72 ng/mL for PRL.

In the descriptive statistics for the continuous data, the average standard deviation (SD), median, minimum and maximum values, and the number of percentages for the discrete data were given. The Shapiro-Wilk test was performed to examine the compatibility of the continuous data with the normal distribution. Mann-Whitney U-test and Student t-test were used to compare continuous variables between the groups. The t-test (paired samples t-test) was used in dependent groups for the data conforming to the normal distribution; and the Wilcoxon test was used for the data that did not show a normal distribution to examine the differences in the hormone values on the basal and trigger days. Chi-square and Fisher's Exact tests were used in group comparisons of nominal variables. The relationships between the continuous data were analysed using Spearman's Correlation Coefficient. The IBM SPSS Statistics version 20 programme was used for evaluations, and a $p$-value of $<0.05$ was accepted to be statistically significant.

\section{RESULTS}

The mean age, $\mathrm{AMH}$ and $\mathrm{BMI}$ of the women included in the study was $26.62 \pm 3.54$ years, $4.66 \pm 3.15 \mathrm{ng} / \mathrm{ml}$ and $26.15 \pm 4.86$ $\mathrm{Kg} / \mathrm{m}^{2}$, respectively. 
Table I: Comparison of basal day and trigger day hormone values of the groups.

\begin{tabular}{|c|c|c|c|c|c|}
\hline & & $\begin{array}{c}\text { Basal day } \\
\text { Mean } \pm \text { SD } \\
\text { Median (Min-Max) }\end{array}$ & $\begin{array}{c}\text { Trigger day } \\
\text { Mean } \pm \text { SD } \\
\text { Median (Min-Max) }\end{array}$ & $\begin{array}{c}\text { Test } \\
\text { statistics }\end{array}$ & p-value \\
\hline \multirow{4}{*}{$\mathrm{FSH}(\mathrm{mlU} / \mathrm{mL})$} & Group I & $\begin{array}{c}7.29 \pm 1.78 \\
7.12(4.15-12.58)\end{array}$ & & & \\
\hline & Group II & $\begin{array}{c}7.37 \pm 1.26 \\
7.79(4.98-9.16)\end{array}$ & $\begin{array}{c}6.72 \pm 2.68 \\
6.11(3.88-15)\end{array}$ & $Z=-2.298$ & 0.022 \\
\hline & Test statistics & $\mathrm{U}=1119.5$ & & & \\
\hline & p-value & 0.464 & & & \\
\hline \multirow{4}{*}{ LH (mlU/mL) } & Group I & $\begin{array}{c}6.06 \pm 3.20 \\
5.43(0.70-13.63)\end{array}$ & & & \\
\hline & Group II & $\begin{array}{c}5.72 \pm 2.44 \\
5.30(1.70-14.14)\end{array}$ & $\begin{array}{c}17.76 \pm 7.54 \\
13.62(5.20-35)\end{array}$ & $Z=-5.990$ & $<0.001$ \\
\hline & Test statistics & $\mathrm{U}=1177.5$ & & & \\
\hline & p-value & 0.745 & & & \\
\hline \multirow{4}{*}{$\mathrm{E}_{2}(\mathrm{pg} / \mathrm{mL})$} & Group I & $\begin{array}{l}39.19 \pm 15.20 \\
36.4(4.3-84)\end{array}$ & & & \\
\hline & Group II & $\begin{array}{c}41.08 \pm 17.90 \\
36.2(17.7-93) \\
\end{array}$ & $\begin{array}{c}380.02 \pm 252.06 \\
411.7(45-785.7)\end{array}$ & $Z=-6.031$ & $<0.001$ \\
\hline & Test statistics & $\mathrm{U}=1179.0$ & & & \\
\hline & p-value & 0.753 & & & \\
\hline \multirow{4}{*}{$P_{4}(n g / m L)$} & Group I & $\begin{array}{c}0.65 \pm 0.45 \\
0.55(0.05-1.91)\end{array}$ & & & \\
\hline & Group II & $\begin{array}{c}0.54 \pm 0.19 \\
0.56(0.17-0.90) \\
\end{array}$ & $\begin{array}{c}1.13 \pm 0.74 \\
1.01(0.28-3.60)\end{array}$ & $Z=-4.985$ & $<0.001$ \\
\hline & Test statistics & $\mathrm{U}=1177.000$ & & & \\
\hline & $p$-value & 0.742 & & & \\
\hline \multirow{4}{*}{$\mathrm{A}_{4}(\mathrm{ng} / \mathrm{mL})$} & Group I & $\begin{array}{c}1.04 \pm 0.45 \\
0.97(0.39-2.11)\end{array}$ & & & \\
\hline & Group II & $\begin{array}{c}0.95 \pm 0.58 \\
0.79(0.50-2.86)\end{array}$ & $\begin{array}{c}1.58 \pm 0.61 \\
1.62(0.64-2.92)\end{array}$ & $Z=-4.832$ & $<0.001$ \\
\hline & Test statistics & $U=701.5$ & & & \\
\hline & p-value & 0.055 & & & \\
\hline \multirow{4}{*}{ DHEA-S ( $\mu \mathrm{g} / \mathrm{dL})$} & Group I & $\begin{array}{c}200.76 \pm 74.60 \\
178.6(91.2-361.2)\end{array}$ & & & \\
\hline & Group II & $\begin{array}{c}239.23 \pm 80.14 \\
225.7(117-410)\end{array}$ & $\begin{array}{l}236.42 \pm 96.87 \\
242.4(92-464)\end{array}$ & $Z=-0.648$ & 0.517 \\
\hline & Test statistics & $\mathrm{U}=629.50$ & & & \\
\hline & p-value & 0.011 & & & \\
\hline \multirow{4}{*}{$\mathrm{T}(\mathrm{ng} / \mathrm{mL})$} & Group I & $\begin{array}{c}0.48 \pm 0.19 \\
0.43(0.13-0.98)\end{array}$ & & & \\
\hline & Group II & $\begin{array}{c}0.48 \pm 0.20 \\
0.47(0.10-0.90)\end{array}$ & $\begin{array}{c}0.61 \pm 0.19 \\
0.58(0.30-0.95)\end{array}$ & $Z=-4.928$ & $<0.001$ \\
\hline & Test statistics & $\mathrm{U}=870.0$ & & & \\
\hline & $p$-value & 0.641 & & & \\
\hline \multirow{4}{*}{$170 \mathrm{HP}(\mathrm{ng} / \mathrm{mL})$} & Group I & $\begin{array}{c}1.84 \pm 0.60 \\
1.91(0.86-2.88)\end{array}$ & & & \\
\hline & Group II & $\begin{array}{c}0.98 \pm 0.89 \\
0.20(0.15-2.10)\end{array}$ & $\begin{array}{c}2.57 \pm 2.22 \\
2.16(2-3.37)\end{array}$ & $Z=-3.181$ & $<0.001$ \\
\hline & Test statistics & $\mathrm{U}=116.0$ & & & \\
\hline & p-value & 0.010 & & & \\
\hline
\end{tabular}

Table II: Comparison of hormone values on basal day and trigger day in women who used CC 100 mg with and without follicle development.

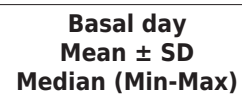

Basal day
Mean \pm SD

Median (Min-Max)

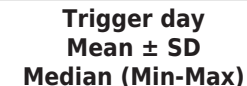

Mean \pm SD

Median (Min-Max) 


\begin{tabular}{|c|c|c|c|c|c|}
\hline \multirow{4}{*}{$\mathrm{FSH}(\mathrm{mlU} / \mathrm{mL})$} & No fol. dev. $(n=7)$ & $\begin{array}{c}6.44 \pm 1.00 \\
7.22(5.36-7.26)\end{array}$ & & & \\
\hline & Fol. dev. $(n=41)$ & $\begin{array}{c}7.53 \pm 1.24 \\
8.14(4.98-9.16)\end{array}$ & $\begin{array}{c}6.59 \pm 2.86 \\
5.97(3.88-15)\end{array}$ & $Z=-2.922$ & $<0.001$ \\
\hline & Test statistics & $U=65.0$ & & & \\
\hline & p-value & 0.020 & & & \\
\hline \multirow{4}{*}{$\mathrm{LH}(\mathrm{mlU} / \mathrm{mL})$} & No fol. dev. & $\begin{array}{c}4.76 \pm 0.42 \\
5.08(4.30-5.15)\end{array}$ & & & \\
\hline & Fol. dev. & $\begin{array}{c}5.88 \pm 2.60 \\
5.32(1.70-14.14)\end{array}$ & $\begin{array}{c}14.06 \pm 7.75 \\
12.3(5.20-35)\end{array}$ & $Z=-5.527$ & $<0.001$ \\
\hline & Test statistics & $\mathrm{U}=80.5$ & & & \\
\hline & p-value & 0.065 & & & \\
\hline \multirow{4}{*}{$E_{2}(p g / m L)$} & No fol. dev. & $\begin{array}{c}39.11 \pm 4.56 \\
36(34-44)\end{array}$ & & & \\
\hline & Fol. dev. & $\begin{array}{c}41.42 \pm 19.30 \\
36.5(17.70-93)\end{array}$ & $\begin{array}{c}434.65 \pm 231.62 \\
522(49.30-785.7)\end{array}$ & $Z=-5.579$ & $<0.001$ \\
\hline & Test statistics & $U=139.5$ & & & \\
\hline & p-value & 0.909 & & & \\
\hline \multirow{4}{*}{$\mathrm{P}_{4}(\mathrm{ng} / \mathrm{mL})$} & No fol. dev. & $\begin{array}{c}0.58 \pm 0.02 \\
0.60(0.55-0.60)\end{array}$ & & & \\
\hline & Fol. dev. & $\begin{array}{c}0.54 \pm 0.20 \\
0.56(0.17-0.90)\end{array}$ & $\begin{array}{c}1.21 \pm 0.76 \\
1.02(0.42-3.60)\end{array}$ & $Z=-4.934$ & $<0.001$ \\
\hline & Test statistics & $\mathrm{U}=126.0$ & & & \\
\hline & p-value & 0.627 & & & \\
\hline \multirow{4}{*}{$\mathrm{A}_{4}(\mathrm{ng} / \mathrm{mL})$} & No fol. dev. & $\begin{array}{c}0.85 \pm 0.09 \\
0.92(0.75-0.93)\end{array}$ & & & \\
\hline & Fol. dev. & $\begin{array}{c}0.95 \pm 0.60 \\
0.78(0.50-2.86)\end{array}$ & $\begin{array}{c}5.57 \pm 25.85 \\
1.62(0.64-167)\end{array}$ & $Z=-4.581$ & $<0.001$ \\
\hline & Test statistics & $\mathrm{U}=106.0$ & & & \\
\hline & $\mathrm{p}$ value & 0.287 & & & \\
\hline \multirow{4}{*}{ DHEA-S $(\mu \mathrm{g} / \mathrm{dL})$} & No fol. dev. & $\begin{array}{c}181.17 \pm 24.85 \\
198(154.5-203.5)\end{array}$ & & & \\
\hline & Fol. dev. & $\begin{array}{c}245.42 \pm 79.54 \\
240.3(117-410)\end{array}$ & $\begin{array}{c}243.73 \pm 96.36 \\
243(92-464)\end{array}$ & $Z=-0.428$ & 0.669 \\
\hline & Test statistics & $U=73.0$ & & & \\
\hline & p-value & 0.039 & & & \\
\hline \multirow{4}{*}{$\mathrm{T}(\mathrm{ng} / \mathrm{mL})$} & No fol. dev. & $\begin{array}{c}0.35 \pm 0.15 \\
0.43(0.19-0.53)\end{array}$ & & & \\
\hline & Fol. dev. & $\begin{array}{c}0.51 \pm 0.19 \\
0.49(0.10-0.90)\end{array}$ & $\begin{array}{c}0.62 \pm 0.19 \\
0.60(0.30-0.95)\end{array}$ & $Z=-4.649$ & $<0.001$ \\
\hline & Test statistics & $U=83.5$ & & & \\
\hline & p-value & 0.080 & & & \\
\hline \multirow{4}{*}{$170 H P(n g / m L)$} & No fol. dev. & $\begin{array}{c}1.10 \pm 0.66 \\
0.97(0.30-2.29)\end{array}$ & & & \\
\hline & Fol. dev. $(n=41)$ & $\begin{array}{c}1.03 \pm 0.82 \\
0.90(0.15-2.10)\end{array}$ & $\begin{array}{c}2.79 \pm 0.66 \\
2.94(2.0-3.89) \\
\end{array}$ & $Z=-3.622$ & $<0.001$ \\
\hline & Test statistics & $U=61.0$ & & & \\
\hline & p-value & 0.372 & & & \\
\hline
\end{tabular}

Table III: Comparison of hormone values on the basal day and trigger day of the cycles that resulted in conception and those that did not result in women using $\mathrm{CC100} \mathrm{mg}$.

\begin{tabular}{|c|c|c|c|}
\hline Basal day & Trigger day & Test & \\
Mean \pm SD & Mean \pm SD & p-value \\
Median (Min-Max) & Median (Min-Max) & & \\
\hline
\end{tabular}




\begin{tabular}{|c|c|c|c|c|c|}
\hline \multirow{4}{*}{$\mathrm{FSH}(\mathrm{mlU} / \mathrm{mL})$} & Conception $(n=11)$ & $\begin{array}{c}7.03 \pm 1.21 \\
7.24(5.64-8.58)\end{array}$ & $\begin{array}{c}5.14 \pm 1.47 \\
4.2(3.88-7.40)\end{array}$ & $Z=-2.847$ & 0.004 \\
\hline & No conception $(n=37)$ & $\begin{array}{c}7.47 \pm 1.27 \\
8(4.98-9.16)\end{array}$ & $\begin{array}{c}7.19 \pm 2.79 \\
6.11(4.15-15)\end{array}$ & $Z=-1.184$ & 0.236 \\
\hline & Test statistics & $\mathrm{U}=171.5$ & $\mathrm{U}=104.5$ & & \\
\hline & $p$-value & 0.432 & 0.015 & & \\
\hline \multirow{4}{*}{$\mathrm{LH}(\mathrm{mlU} / \mathrm{mL})$} & Conception & $\begin{array}{c}4.98 \pm 0.85 \\
5.1(3.73-5.90)\end{array}$ & $\begin{array}{c}18.38 \pm 8.54 \\
23.42(5.20-25)\end{array}$ & $Z=-2.934$ & 0.003 \\
\hline & No conception & $\begin{array}{c}5.94 \pm 2.71 \\
5.31(1.70-14.14)\end{array}$ & $\begin{array}{c}13.68 \pm 6.99 \\
14.40(5.45-35)\end{array}$ & $Z=-5.243$ & $<0.001$ \\
\hline & Test statistics & $\mathrm{U}=153.5$ & $\mathrm{U}=135.0$ & & \\
\hline & $p$-value & 0.220 & 0.093 & & \\
\hline \multirow{4}{*}{$E_{2}(p g / m L)$} & Conception & $\begin{array}{c}45.00 \pm 7.76 \\
48.60(34-53)\end{array}$ & $\begin{array}{c}429.84 \pm 308.41 \\
570(45-711)\end{array}$ & $Z=-2.936$ & 0.003 \\
\hline & No conception & $\begin{array}{l}39.91 \pm 19.88 \\
34(17.70-93) \\
\end{array}$ & $\begin{array}{c}365.21 \pm 235.68 \\
371(49.3-785.7)\end{array}$ & $Z=-5.304$ & $<0.001$ \\
\hline & Test statistics & $\mathrm{U}=134.0$ & $\mathrm{U}=177.0$ & & \\
\hline & p-value & 0.088 & 0.515 & & \\
\hline \multirow{4}{*}{$P_{4}(n g / m L)$} & Conception & $\begin{array}{c}0.69 \pm 0.15 \\
0.60(0.56-0.90)\end{array}$ & $\begin{array}{c}0.98 \pm 0.58 \\
0.96(0.28-1.70)\end{array}$ & $Z=-2.046$ & 0.041 \\
\hline & No conception & $\begin{array}{c}0.49 \pm 0.17 \\
0.55(0.17-0.81)\end{array}$ & $\begin{array}{c}1.17 \pm 0.78 \\
1.06(0.42-3.60)\end{array}$ & $Z=-4.558$ & $<0.001$ \\
\hline & Test statistics & $U=95.0$ & $U=172.0$ & & \\
\hline & $p$-value & 0.008 & 0.439 & & \\
\hline \multirow{4}{*}{$\mathrm{A}_{4}(\mathrm{ng} / \mathrm{mL})$} & Conception & $\begin{array}{c}0.79 \pm 0.15 \\
0.76(0.60-0.95)\end{array}$ & $\begin{array}{c}1.32 \pm 0.35 \\
1.27(0.96-1.86)\end{array}$ & $Z=-2.934$ & 0.003 \\
\hline & No conception & $\begin{array}{c}0.98 \pm 0.62 \\
0.78(0.50-2.86) \\
\end{array}$ & $\begin{array}{c}6.06 \pm 27.20 \\
1.63(0.64-167) \\
\end{array}$ & $Z=-4.293$ & $<0.001$ \\
\hline & Test statistics & $U=202.0$ & $U=165.5$ & & \\
\hline & $\mathrm{p}$-value & 0.971 & 0.350 & & \\
\hline \multirow{4}{*}{ DHEA-S $(\mu \mathrm{g} / \mathrm{dL})$} & Conception & \begin{tabular}{|c|}
$226.79 \pm 32.35$ \\
$204.5(198-278)$
\end{tabular} & $\begin{array}{c}243.07 \pm 20.74 \\
244.9(219-272)\end{array}$ & $Z=-2.134$ & 0.033 \\
\hline & No conception & $\begin{array}{c}238.80 \pm 86.57 \\
190.10(117-410)\end{array}$ & $\begin{array}{c}232.77 \pm 105.31 \\
232(92-464)\end{array}$ & $Z=-1.177$ & 0.239 \\
\hline & Test statistics & $\mathrm{U}=182.0$ & $\mathrm{U}=163.0$ & & \\
\hline & $p$-value & 0.598 & 0.320 & & \\
\hline \multirow{4}{*}{$\mathrm{T}(\mathrm{ng} / \mathrm{mL})$} & Conception & $\begin{array}{c}0.54 \pm 0.15 \\
0.46(0.39-0.75) \\
\end{array}$ & $\begin{array}{c}0.58 \pm 0.23 \\
0.50(0.32-0.90)\end{array}$ & $Z=-1.026$ & 0.305 \\
\hline & No conception & $\begin{array}{c}0.46 \pm 0.19 \\
0.47(0.10-0.90)\end{array}$ & $\begin{array}{c}0.59 \pm 0.18 \\
0.58(0.30-0.95)\end{array}$ & $Z=-4.237$ & $<0.001$ \\
\hline & Test statistics & $\mathrm{U}=154.5$ & $\mathrm{U}=194.5$ & & \\
\hline & $\mathrm{p}$-value & 0.229 & 0.825 & & \\
\hline \multirow{4}{*}{ 170HP (ng/mL) } & Conception & $\begin{array}{c}1.28 \pm 0.49 \\
1.22(0.48-1.49)\end{array}$ & $\begin{array}{c}2.83 \pm 0.74 \\
2.37(2.14-3.89)\end{array}$ & $Z=-2.936$ & 0.003 \\
\hline & No conception & $\begin{array}{c}0.83 \pm 0.92 \\
0.20(0.15-2.29)\end{array}$ & $\begin{array}{c}2.64 \pm 0.56 \\
2.66(2.0-3.37) \\
\end{array}$ & $Z=-3.059$ & 0.002 \\
\hline & Test statistics & $\mathrm{U}=76.0$ & $\mathrm{U}=79.0$ & & \\
\hline & $\mathrm{p}$-value & 0.089 & 0.212 & & \\
\hline
\end{tabular}

In Group II, the serum FSH values on the trigger day were statistically significantly lower $(p=0.022)$; while the serum $\mathrm{LH}, \mathrm{E}_{2}, \mathrm{P}_{4}, \mathrm{~A}_{4}, \mathrm{~T}$ and 17-OHP values were significantly higher (Table I), compared to the basal day. In Group II, the basal day DHEA-S values were significantly higher $(p=0.011)$ and the basal day 17-OHP values were significantly lower compared to those of Group I ( $p=0.01$, Table I).

In Group II, 41 (85.4\%) of the 48 women, given CC 100 mg, had follicle development. When the trigger day hormone levels of the patients with follicle development were compared to the basal day, FSH was found to be significantly lower $(p<0.001)$, and the $L H, E_{2}, P_{4}, A_{4}, T$ and 17-OHP values were found to be significantly higher $(p<0.001)$. The women with follicle development had higher FSH and DHEA-S values on the basal day than the women without follicle development ( $p=0.02, p=0.039$, respectively, Table II).

Eleven (22.9\%) of 48 women who used CC $100 \mathrm{mg}$ had conceived. The trigger day FSH value was found to be signifi- 
cantly lower in patients who conceived compared to the basal day $(p=0.004)$. The high $P_{4}$ value $(p=0.008)$ on the basal day and the low FSH value $(p=0.015)$ on the trigger day were found to be statistically significantly different in the women who had conceived compared to those who had not conceived (Table III).

The increase in the LH values on the trigger day was significantly higher in the women who had conceived compared to the basal day ( $p=0.023$ ). No difference was found among the FSH, $E_{2}, P_{4}, A_{4}$, DHEA-S and T change values on the trigger day compared to the basal day of the women had and had not conceived ( $p>0.05)$.

\section{DISCUSSION}

In this study, Group I consisted entirely of anovulatuary cycles and Group II consisted of cycles with $85.4 \%$ follicle development. In Group II, the LH, $\mathrm{E}_{2}, \mathrm{P}_{4}, \mathrm{~A}_{4}, \mathrm{~T}$ and 17-OHP values increased significantly on the trigger day compared to the basal day. In contrast, the FSH and DHEA-S values were found to be lower on the trigger day compared to the basal day. In the natural ovulatory menstrual cycles, the $\mathrm{GnRH}$ pulse frequency increases in the late luteal/early follicular phase, resulting in an increase in serum FSH concentration. ${ }^{7}$ The mild increase in $\mathrm{FSH}$ secretion stimulates $\mathrm{E}_{2}$ production and folliculogenesis. ${ }^{8}$ There is also a rapid increase in LH pulse in the early follicular phase. Serum FSH and LH concentrations fall in the late follicular phase due to the negative feedback effects of $E_{2}$. All other hormones increase significantly with follicular development. ${ }^{9}$ In CC-induced cycles, FSH increases with the first dose of CC; however, with the last dose, it begins to decrease towards the midcycle. ${ }^{10}$ In a study by Opsahl et al., CC in 19 anovulatory infertile women receiving cyclic, incremental therapy for ovulation induction treatment cycles found that the FSH value on the $10^{\text {th }}$ day of the cycle in ovulatory cycles was significantly higher than in the anovulatory cycles. However, they had demonstrated that gonadotropin response patterns, follicular development, endometrial growth, maturation, peak serum $E_{2}$ and $P_{4}$ concentrations remained consistent throughout consecutive CC treatment cycles; and did not change with the number of cycles. They suggested that success in CC ovulation induction depends on the degree of increasing $\mathrm{FSH}$ concentrations in response to the treatment. ${ }^{11}$ In this study, as Group II mostly consisted of ovulatory cycles, the authors found the change in the hormonal pattern compatible with the natural cycle. Since the authors did not measure hormones in the mid-follicular phase in this study, they could not catch the peak in FSH increase. However, they were able to demonstrate the FSH reduction prior to ovulation.

In this study, the authors also examined other steroid hormone responses. High DHEA-S and low 17-OHP values on the basal day in Group II can be considered to predict ovulation since most of them consist of ovulation cycles. It was surmised that the relatively increased FSH (contingent upon it was not exceeding the $12.5 \mathrm{mIU} / \mathrm{mL}$ threshold) and DHEA-S values on the basal day, and the more significant decrease in these hormones on the trigger day were also related to the development of the follicle. In addition, it was concluded that the relative increase in the $P_{4}$ values (not exceeding the $0.5 \mathrm{ng} / \mathrm{mL}$ threshold) on the basal day, the significant decrease in FSH and the significant increase in $\mathrm{LH}$ on the trigger day were associated with conception.

No study could be found in the literature that would explain the reason for $\mathrm{CC}$ not responding in some cycles or regarding the clinical significance of hormonal changes created by step-up CC cycles in patients with unexplained infertility. However, there are many studies with conflicting results regarding hormonal changes in response to gonadotropins in ICSI cycles. Ferrario et al. showed that there was a positive correlation between basal DHEA-S levels and mature oocyte count, fertilised oocyte, and embryo development in ICSI cycles of a group of older women with low responses; whereas, the basal serum androstenedione level was positively correlated only in those who could conceive. ${ }^{12}$ As in this study, the authors found that women who were able to develop follicles in response to CC only, had higher basal DHEA-S levels. However, it was not possible to determine the clinical importance of the minimum decrease in the DHEA-S level on the trigger day. In contrast, Abide et al. have shown in a study of 120 women with diminished ovarian reserve ICSI cycles that basal serum T and DHEA-S levels have no value in predicting any of the cycle outcome parameters. ${ }^{13}$ In a study of 164 infertile women with PCOS, no significant difference was found between CC-sensitive and CC-resistant groups in levels of serum FSH and 17-OHP. ${ }^{14}$

Androgens play a role in follicle recruitment and promotion of follicle growth. ${ }^{15,16} \mathrm{~A}_{4}$, DHEA-S, dehydroepiandrosterone (DHEA), T and dihydrotestosterone (DHT) are the major androgens in the serum of normal women. ${ }^{17}$ While there are some studies showing that serum AMH levels increase significantly after DHEA supplementation, ${ }^{18,19}$ there are also studies showing no change of serum AMH levels. ${ }^{20}$ In addition to improving the ovarian response, androgen pre-treatment in IVF has been reported to increase antral follicles, oocyte and embryo numbers, pregnancy and live births as well as see an improvement in embryo quality in IVF. ${ }^{21}$ DHEA-S levels on the basal day was in a positive correlation with follicular development in the present study.

Studies examining the relationship between 17-OHP and follicle development are even more limited. Fanelli et al. showed that androgens did not change during the menstrual cycle; however, the upper level of T and 17-OHP were higher in the luteal phase than in the follicular phase. ${ }^{22}$ In this study, the 17-OHP level was lower in Group II on the basal day. However, the authors did not examine the hormones of 
the luteal period. The authors also determined that it tended to increase T levels when approaching the trigger day.

In CC cycles, pregnancy rates per cycle are reported to be $11.4 \%-21.5 \%$ in ovulatory women ${ }^{23}$ and $9.7 \%-24.6 \%$ in anovulatory women. ${ }^{24}$ Pregnancy rates in Group II were $22.9 \%$. The cumulative pregnancy rate after six cycles of CC with the conventional step-up regimen was reported to be $55 \%-73 \%{ }^{25}$ The results of the present study were consistent with the current data. In addition, an increase in LH was observed more prominently in cycles developing conception. The greater the hormonal response, the greater the follicular development. Due to the intervention of the COVID-19 pandemic, the authors could not follow the pregnancies exactly. However, when the records were examined retrospectively, it was observed that three out of eleven pregnant women resulted in live births and four resulted in miscarriages. However, the information of four of the women could not be accessed.

All the findings in this study showed that the cycles that responded to $\mathrm{CC}$ in women with unexplained infertility have higher FSH and DHEA-S at the baseline, consistent with the magnitude of the decrease on the trigger day, and which can predict ovulation. The higher basal $\mathrm{P}_{4}$ and the magnitude of the $\mathrm{LH}$ response may predict pregnancy.

The small sample size and the absence of the placebo group were significant limitations in this study.

\section{CONCLUSION}

The level of FSH and DHEA-S in the baseline in addition to the severity of the decrease on the trigger day determine the follicle development in CC cycles. The decrease of FSH towards the trigger day and the magnitude of the LH surge also appear to be related to pregnancy. However, it is unknown as to whether all this is a cause or an effect. Therefore, more large-scale, well-controlled clinical studies are required to be able to predict ovulation and obtain hormonal threshold values.

\section{ETHICAL APPROVAL:}

For this study, the ethical approval was obtained from the local Ethics Committee of Bagcilar Training and Research Hospital (Approval No. 2019.08.1.04.061).

\section{PATIENTS' CONSENT:}

All patients signed a document of informed consent.

\section{CONFLICT OF INTEREST:}

The authors declared no conflict of interest.

\section{AUTHORS' CONTRIBUTION}

EEK: Study concept and design, acquisition of data, analysis and interpretation of data and drafting of manuscript. SEO: Revising it critically for important intellectual content. OKA: Acquisition of data, analysis and interpretation of data.
TK: Final approval of the version to be published.

\section{REFERENCES}

1. Allahbadia GN. Oral drugs for unexplained Infertility. J Obstet Gynaecol India 2016; 66(1):1-5. doi: 10.1007/ s13224-015-0805-7.

2. Amirian M, Shariat Moghani S, Jafarian F, Mirteimouri M, Nikdoust $S$, Niroumand $S$, et al. Combination of pioglitazone and clomiphene citrate versus clomiphene citrate alone for infertile women with the polycystic ovarian syndrome. BMC Womens Health 2021; 21(1):302. doi: 10.1186/s12905021-01448-5.

3. Morgante G, Massaro MG, Di Sabatino A, Cappelli V, De Leo V. Therapeutic approach for metabolic disorders and infertility in women with PCOS. Gynecol Endocrinol 2018; 34(1): 4-9. doi: 10.1080/09513590.2017.1370644.

4. Hughes E, Brown J, Collins JJ, Vanderkerchove P. Clomiphene citrate for unexplained subfertility in women. Cochrane Database Syst Rev 2010; 2010(1):CD000057. doi: 10.1002/ 14651858.

5. Shahgheibi S, Seyedoshohadaei F, Khezri D, Ghasemi S. Endometrial and follicular development following stair-step and traditional protocols in women with polycystic ovary syndrome: An RCT. Int J Reprod Biomed 2021; 19(6): 537-44. doi: 10.18502/ijrm.v19i6.9375.

6. Ozyurek ES, Yoldemir T, Artar G. Androstenedione response to recombinant human FSH is the most valid predictor of the number of selected follicles in polycystic ovarian syndrome: (a case-control study). J Ovarian Res 2017; 10(1):34. doi: 10.1186/s13048-017-0330-7.

7. Hall JE, Schoenfeld DA, Martin KA, Crowley WF Jr. Hypothalamic gonadotropin-releasing hormone secretion and follicle-stimulating hormone dynamics during the luteal-follicular transition. J Clin Endocrinol Metab 1992; 74(3):600-7. doi: 10.1210/jcem.74.3.1740493.

8. Welt CK, Martin KA, Taylor AE, Lambert-Messerlian GM, Crowley WF Jr. Frequency modulation of follicle-stimulating hormone (FSH) during the luteal-follicular transition: Evidence for FSH control of inhibin B in normal women. J Clin Endocrinol Metab 1997; 82(8):2645-52. doi: 10.1210/ jcem.82.8.4138.

9. Fritz MA, Speroff L. Clinical gynecologic endocrinology and Infertility, 8th edition. Philadelphia: Lippincott Williams \& Wilkins; 2011.pp. 208-9.

10. Kettel LM, Roseff SJ, Berga SL, Mortola JF, Yen SS. Hypothalamic-pituitary-ovarian response to clomiphene citrate in women with polycystic ovary syndrome. Fertil Steril 1993; 59(3):532-8.

11. Opsahl MS, Robins ED, O'Connor DM, Scott RT, Fritz MA. Characteristics of gonadotropin response, follicular development, and endometrial growth and maturation across consecutive cycles of clomiphene citrate treatment. Fertil Steril 1996; 66(4):533-9.

12. Ferrario $M$, Secomandi $R$, Cappato $M$, Galbignani E, Frigerio L. Ovarian and adrenal androgens may be useful markers to predict oocyte competence and embryo development in older women. Gynecol Endocrinol 2015; 31(2):125-30. doi: 10.3109/09513590.2014.964639. 
13. Abide Yayla C, Ozkaya E, Kayatas Eser S, Sanverdi I, Devranoglu B. Association of basal serum androgen levels with ovarian response and ICSI cycle outcome. Ir J Med Sci 2018; 187(2):409-15. doi: 10.1007/s11845-017-1665-1.

14. Sachdeva G, Gainder S, Suri V, Sachdeva N, Chopra S. Comparison of clinical, metabolic, hormonal, and ultrasound parameters among the clomiphene citrate-resistant and clomiphene citrate-sensitive polycystic ovary syndrome women. J Hum Reprod Sci 2019; 12(3):216-23. doi: 10.4103/jhrs.JHRS_89_18.

15. Sahu P, Gidwani B, Dhongade HJ. Pharmacological activities of dehydroepiandrosterone: A review. Steroids 2020; 153:108507. doi: 10.1016/j.steroids.2019.108507.

16. Dewailly D, Robin G, Peigne M, Decanter C, Pigny $P$, Catteau-Jonard $\mathrm{S}$, et al. Interactions between androgens, $\mathrm{FSH}$, anti-Müllerian hormone and estradiol during folliculogenesis in the human normal and polycystic ovary. Hum Reprod Update 2016; 22(6):709-24. doi: 10.1093/ humupd/dmw027.

17. Davison SL, Davis SR. Androgens in women. J Steroid Biochem Mol Biol 2003; 85(2-5):363-6. doi: 10.1016/ s0960-0760(03)00204-8.

18. Agarwal R, Shruthi R, Radhakrishnan G, Singh A. Evaluation of dehydroepiandrosterone supplementation on diminished ovarian reserve: A randomised, double-blinded, placebo-controlled study. J Obstet Gynaecol India 2017; 67(2):137-42. doi: 10.1007/s13224-016-0941-8.

19. Lin LT, Tsui KH. The relationships between serum DHEA-S and $\mathrm{AMH}$ levels in Infertile women: A retrospective cross-sectional study. J Clin Med 2021; 10(6):1211. doi: 10.3390/ jcm10061211.
20. Hu Q, Hong L, Nie M, Wang Q, Fang Y, Dai Y, et al. The effect of dehydroepiandrosterone supplementation on ovarian response is associated with androgen receptor in diminished ovarian reserve women. J Ovarian Res 2017; 10(1):32. doi: 10.1186/s13048-017-0326-3.

21. Wiser A, Gonen O, Ghetler Y, Shavit T, Berkovitz A, Shulman A. Addition of dehydroepiandrosterone (DHEA) for poor-responder patients before and during IVF treatment improves the pregnancy rate: A randomised prospective study. Hum Reprod 2010; 25(10):2496-500. doi: 10.1093/humrep/deq220.

22. Fanelli F, Gambineri A, Belluomo I, Repaci A, Di Lallo VD, Di Dalmazi $G$, et al. Androgen profiling by liquid chromatography-tandem mass spectrometry (LC-MS/MS) in healthy normal-weight ovulatory and anovulatory late adolescent and young women. J Clin Endocrinol Metab 2013; 98(7):3058-67. doi: 10.1210/jc.2013-1381.

23. El Hachem H, Antaki R, Sylvestre C, Kadoch IJ, Lapensée L, Emmanuel Bouet P. Clomiphene citrate versus letrozole for ovarian stimulation in therapeutic donor sperm Insemination. Gynecol Obstet Invest 2017; 82(5):481-6. doi: 10.1159/000452665.

24. Vlahos NF, Coker L, Lawler C, Zhao Y, Bankowski B, Wallach EE. Women with ovulatory dysfunction undergoing ovarian stimulation with clomiphene citrate for intrauterine insemination may benefit from administration of human chorionic gonadotropin. Fertil Steril 2005; 83(5):1510-6. doi: 10.1016/j. fertnstert.2004.11.049.

25. Thessaloniki ESHRE/ASRM-sponsored PCOS consensus workshop group. consensus on infertility treatment related to polycystic ovary syndrome. Hum Reprod 2008; 23(3): 462-77. doi: 10.1093/humrep/dem426. 